\title{
ANALISIS PENGARUH UKURAN PERUSAHAAN, PROFITABILITAS, LEVERAGE DAN UKURAN DEWAN KOMISARIS TERHADAP PENGUNGKAPAN TANGGUNGJAWAB SOSIAL PERUSAHAAN (CORPORATE SOCIAL RESPONSIBILITY)
}

\author{
DESRIR MIFTAH, ZAINAL ARIFIN \\ desrir_miftah@yahoo.com \\ Fakultas Ekonomi dan Ilmu Sosial UIN Suska Riau
}

\begin{abstract}
ABSTRAK
Penelitian ini bertujuan untuk menguji pengaruh Ukuran Perusahaan, Profitabilitas, Leverage dan Ukuran Dewan Komisaris terhadap Pengungkapan Tanggungjawab Sosial Perusahaan (Corporate Social Responsibility) pada perusahaan Manufaktur yang terdaftar di Bursa Efek Indonesia periode tahun 2009-2011.

Pemilihan sampel dalam penelitian ini menggunakan metode purposive sampling dengan jumlah 32 perusahaan. Teknik analisis dilakukan dengan regresi linear berganda. Pengujian hipotesis dengan menggunakan uji t untuk menguji pengaruh secara parsial. Sebelumnya dilakukan uji normalitas dan uji asumsi klasik.

Hasil penelitian menunjukkan bahwa Ukuran Perusahaan berpengaruh signifikan terhadap Pengungkapan Tanggunjawab Sosial Perusahaan, Leverage berpengaruh signifikan dengan arah negatif terhadap Pengungkapan Tanggungjawab Sosial Perusahaan. Sedangkan Profitabilitas dan Ukuran Dewan Komisaris tidak berpengaruh terhadap Pengungkapan Tanggungjawab Sosial Perusahaan.
\end{abstract}

Kata kunci : Ukuran Perusahaan, Profitabilitas, Leverage, Ukuran Dewan Komisaris, Pengungkapan Tanggungjawab Sosial Perusahaan

\section{PENDAHULUAN}

Lingkungan yang berada disekitar perusahaan merupakan alasan utama berdirinya suatu perusahaan. Aktifitas perusahaan dalam usaha memperoleh laba akan berkaitan dengan perolehan bahan baku yang berasal dari lingkungan, penggunaan tenaga kerja dan pemasaran barang jadi yang kembali ke lingkungan. Perkembangan dunia saat ini menuntut perusahaan untuk meningkatkan perhatiannya kepada lingkungan sosial. Perusahaan tidak hanya mengutamakan kepentingan manajemen dan stakeholders, tetapi juga karyawan, konsumen, masyarakat dan lingkungannya.

Informasi mengenai sejauh mana perusahaan telah melaksanakan aktivitas sosialnya sangat dibutuhkan olah masyarakat. Akuntansi konvensional menuai kritikan karena dianggap belum mampu mengakomodir kepentingan masyarakat secara luas, sehingga pada akhirnya menghadirkan konsep akuntansi yang dikenal sebagai Akuntansi Pertanggungjawaban Sosial (Anggraini, 2006). Kesadaran stakeholders akan pentingnya pembangunan berkelanjutan, mendorong perusahaan untuk mengungkapkan praktik-praktik atau kegiatan tanggungjawab sosial perusahaan (Corporate Social Responsibility/CSR). Menurut Deegan dan Gordon (1996) dalam Jose dan Lee (2006) bahwa tekanan stakeholders terhadap perusahaan untuk dapat secara efektif menjalankan kegiatan lingkungannya serta tuntutan agar perusahaan menjadi akuntabel juga menyebabkan meningkatnya perusahaan yang melakukan pengungkapan lingkungan. Selain itu, Owen (2005) mengatakan bahwa kasus Enron di 
Amerika telah menyebabkan perusahaan lebih memberikan perhatian yang besar terhadap pelaporan sustainabilitas dan pertanggungjawaban sosial perusahaan.

Catatan keuangan perusahaan harus memperhatikan aspek keuangan, sosial, dan lingkungan (Triple bottom line) yang merupakan kunci dari konsep pembangunan berkelanjutan. Pentingnya pengungkapan CSR telah mendorong banyak penelitian mengenai faktor-faktor yang mempengaruhi pengungkapan CSR. Di antaranya penelitian yang dilakukan oleh Belkaoui dan Krapik (1989), Hackston dan Milne (1996), Sembiring (2005), Anggraeni (2006), Rosmasita (2007), Apriwenni (2009) dan Cahaya (2010). Faktor-faktor yang menjadi variabel dalam penelitian tersebut antara lain ukuran perusahaan, profitabilitas, leverage dan ukuran dewan komisaris.

\section{Perumusan Masalah}

Bagaimana pengaruh ukuran perusahaan, profitabilitas, leverage dan ukuran dewan komisaris terhadap pengungkapan tanggung jawab sosial perusahaan?

\section{Tujuan Penelitian}

Untuk mengetahui pengaruh ukuran perusahaan, profitabilitas, leverage dan ukuran dewan komisaris terhadap pengungkapan tanggung jawab sosial perusahaan.

\section{TELAAH PUSTAKA DAN PENGEMBANGAN HIPOTESIS}

\section{Corporate Social Responsibility (CSR)}

CSR atau tanggung jawab sosial perusahaan merupakan suatu komitmen bisnis untuk memberikan kontribusi dalam pembangunan ekonomi berkelanjutan yang dapat bekerjasama dengan karyawan dan perwakilan mereka, masyarakat sekitar dan masyarakat luas untuk meningkatkan kualitas hidup, dengan cara yang lebih baik bagi bisnis maupun pengembangan (World Bank). Di dalam ISO 26000 dijelaskan tujuh elemen dasar dari praktik CSR yang dapat dilakukan perusahaan, yaitu :

1. Tata kelola perusahaan ; bagaimana perusahaan harus bertindak sebagai elemen dasar dari tanggung jawab sosial dan sebagai sarana untuk meningkatkan kemampuan perusahaan untuk menerapkan perilaku yang bertanggung jawab sosial.

2. Hak asasi manusia ; terbagi menjadi dua yaitu hak-hak sipil dan politik serta hak-hak ekonomi, sosial dan budaya.

3. Ketenagakerjaan; contohnya pelaksanaan kondisi kerja yang baik, bermartabat, kondusif, pengembangan sumber daya manusia dan lain-lain.

4. Lingkungan; mencakup pencegahan polusi sebagai dampak aktivitas perusahaan, pencegahan global warming, pendayagunaan sumber daya alam secara efisien dan efektif, dan penggunaan sistem manajemen lingkungan yang efektif dan berkelanjutan.

5. Praktik operasional yang adil; mencakup pelaksanaan aktivitas secara etik dan pengungkapan aktivitas perusahaan yang transparan, pelaksanaan pemilihan pemasok yang etis dan sehat, penghormatan terhadap hak-hak intelektual dan kepentingan stakeholders, serta perlawanan terhadap korupsi.

6. Konsumen; mencakup penyediaan informasi yang akurat dan relevan tentang produk perusahaan kepada pelanggan, penyediaan produk yang aman dan bermanfaat bagi pelanggan.

7. Keterlibatan dan pengembangan masyarakat; mencakup pengembangan masyarakat, peningkatan kesejahteraan, aktivitas sosial kemasyarakatan dan melibatkan masyarakat di dalam aktivitas operasional perusahaan.

\section{Teori Stakeholder}

Pendekatan stakeholder muncul pada pertengahan tahun 1980-an. Latarbelakang pendekatan ini adalah keinginan untuk 
membangun suatu kerangka kerja yang responsif terhadap masalah yang dihadapi para manajer saat itu yaitu perubahan lingkungan. Tujuan dari manajemen stakeholder adalah untuk merancang metode mengelola berbagai kelompok dan hubungan yang dihasilkan dengan cara yang strategis (Freeman and McVea, 2001).

\section{Teori Agensi}

Prinsip utama teori ini menyatakan adanya hubungan kerja antara pihak yang memberi wewenang (principle) yaitu investor, dengan pihak yang menerima wewenang (agency) yaitu manajer. Teori agensi mengasumsikan bahwa semua individu bertindak atas kepentingan mereka sendiri, sehingga terjadi konflik kepentingan antara pemilik dan agen karena kemungkinan agen tidak selalu berbuat sesuai dengan kepentingan prinsipal, dan memicu biaya keagenan (agency cost).

\section{Pengungkapan Tanggungjawab Sosial Perusahaan}

Menurut Hackston dan Milne, tanggungjawab sosial perusahaan disebut juga corporate social responsibility, social disclosure, corporate social reporting, social reporting merupakan proses pengkomunikasian dampak sosial dan lingkungan dari kegiatan ekonomi organisasi terhadap kelompok khusus yang berkepentingan dan kelompok masyarakat secara keseluruhan (Sembiring, 2005).

\section{Pengaruh Ukuran Perusahaan (Size) terhadap Pengungkapan CSR}

Ukuran perusahaan adalah suatu skala dimana dapat diklasifikasikan besar kecilnya suatu perusahaan. Size perusahaan merupakan variabel yang banyak digunakan untuk menjelaskan pengungkapan sosial yang dilakukan perusahaan. Secara umum perusahaan besar akan mengungkapkan informasi lebih banyak daripada perusahaan kecil karena perusahaan besar akan menghadapi risiko politis yang lebih besar. Dalam penelitian ini indikator yang digunakan untuk mengukur size perusahaan adalah total aktiva.

Pengaruh ukuran perusahaan terhadap CSR tercermin dalam teori agensi yang menjelaskan bahwa perusahaan besar mempunyai biaya agensi yang besar, karenanya perusahaan akan lebih banyak mengungkapkan informasi daripada perusahaan kecil. Penjelasan lain yang juga sering dilakukan adalah perusahaan besar akan memiliki sumber daya yang besar sehingga tidak perlu ada tambahan biaya yang besar untuk dapat melakukan pengungkapan dengan lebih lengkap. Berdasarkan uraian diatas hipotesis 1 dari penelitian ini adalah :

H1 : Terdapat pengaruh signifikan antara ukuran perusahaan terhadap pengungkapan CSR.

\section{Pengaruh Profitabilitas Perusahaan terhadap Pengungkapan CSR}

Profitabilitas adalah kemampuan perusahaan untuk menghasilkan laba dalam upaya meningkatkan nilai pemegang saham. Berdasarkan teori legitimasi, ketika perusahaan memiliki laba yang tinggi, perusahaan tidak perlu melaporkan hal-hal yang menganggu informasi tentang suksesnya keuangan perusahaan, sebaliknya pada saat tingkat profitabilitas rendah, mereka berharap para pengguna laporan akan membaca 'good news' kinerja perusahaan. (Donovan and Gibson, 2000).

Heinze (1976) dalam Heckston dan Milne (1996) menyatakan bahwa profitabilitas merupakan faktor yang memberikan kebebasan dan fleksibilitas kepada manajemen untuk mengungkapkan pertanggungjawaban sosial kepada pemegang saham. Hal ini berarti semakin tinggi tingkat profitabilitas perusahaan maka semakin besar pengungkapan informasi sosial yang dilakukan oleh perusahaan.

H2 : Terdapat Pengaruh Profitabilitas terhadap Pengungkapan CSR 
Pengaruh Leverage Perusahaan terhadap Pengungkapan CSR

Leverage diartikan sebagai tingkat ketergantungan perusahaan terhadap hutang dalam membiayai kegiatan operasinya. Leverage mencerminkan tingkat risiko keuangan perusahaan (Sembiring, 2005). Teori keagenan memprediksi bahwa perusahaan dengan rasio leverage yang lebih tinggi akan mengungkapkan lebih banyak informasi karena biaya keagenan perusahaan dengan struktur modal seperti itu lebih tinggi. (Jensen and Mecking, 1976 dalam Anggraini, 2006).

Scoot (2000) berpendapat bahwa semakin tinggi leverage kemungkinan besar perusahaan akan mengalami pelanggaran terhadap kontrak utang, maka manajer akan berusaha untuk melaporkan laba sekarang lebih tinggi dibandingkan laba dimasa depan. Perusahaan yang memiliki rasio leverage tinggi akan lebih sedikit mengungkapkan CSR supaya dapat melaporkan laba sekarang yang lebih tinggi.

H3 : Terdapat Pengaruh Leverage terhadap Pengungkapan CSR

\section{Pengaruh Ukuran Dewan Komisaris terhadap Pengungkapan CSR}

Ukuran dewan komisaris adalah banyaknya jumlah anggota dewan komisaris dalam perusahaan. Sebagai wakil prinsipal di dalam perusahaan, dewan komisaris dapat mempengaruhi luasnya pengungkapan tanggungjawab sosial. Dewan komisaris sebagai wakil shareholder dalam perusahaan berfungsi mengawasi pengelolaan perusahaan yang dilakukan oleh manajemen (direksi) dan bertanggungjawab untuk menentukan apakah manajemen memenuhi tanggungjawab mereka dalam mengembangkan dan menyelenggarakan pengendalian intern perusahaan (Mulyadi, 2002). Dengan wewenang yang dimiliki, dewan komisaris dapat memberikan pengaruh yang cukup kuat untuk mengungkapkan CSR. Sehingga perusahaan yang memiliki ukuran dewan komisaris yang lebih besar akan lebih banyak mengungkapkan CSR.

\section{Tanggungjawab Sosial dalam Perspekstif Islam}

Dalam konsep Islam, disimpulkan bahwa agama yang diturunkan kepada manusia oleh Allah SWT melalui nabi Muhammad SAW merupakan suatu sistem way of life yang utuh, sesuai dan tidak bertentangan dengan ilmu pengetahuan serta fenomena alam yang ada. Tanggungjawab sosial dalam Islam ditekankan pada tanggungjawab manusia atas perbuatannya kepada sang pencipta. Dalam pandangan Al-Quran, tanggungjawab sosial individu sangat penting karena setiap individu bertanggungjawab terhadap semua yang dilakukannya dan tidak ada seorangpun yang memiliki imunitas untuk menghadapi konsekuensi terhadap apa yang dilakukan. Setiap manusia akan dimintai pertanggungjawaban setiap perbuatan yang dilakukan baik di dunia maupun di akhirat. (Al-Isra : 36).

\section{METODOLOGI PENELITIAN}

\section{Jenis Penelitian}

Jenis penelitian adalah penelitian kausalitas/asosiatif. Penelitian kausalitas merupakan penelitian yang memiliki tujuan untuk menganalisis hubungan antara variabel yang lain atau bagaimana suatu variabel dapat mempengaruhi variabel lainnya.

\section{Populasi dan Sampel Penelitian}

Populasi penelitian adalah perusahaan manufaktur yang terdaftar di Bursa Efek Indonesia periode 2009-2011. Perusahaan manufaktur dipilih karena merupakan perusahaan yang relatif lebih banyak memiliki dampak pada lingkungan dibandingkan dengan perusahaan jasa atau dagang. Sektor manufaktur merupakan sektor yang memiliki cakupan stakeholder paling luas yang meliputi investor, 
kreditor, pemerintah, dan lingkungan sosial sehingga perlu pengungkapan informasi sosial. Penelitian ini berfokus pada sektor manufaktur karena untuk menghindari adanya industrial effect yaitu risiko industri yang berbeda antara suatu sektor industri yang satu dengan yang lain. Penarikan sampel dengan metode purposive sampling. Kriteria yang digunakan meliputi : (1) Perusahaan manufaktur yang terdaftar di BEI dan sahamnya aktif diperdagangkan selama periode 2009-2011. (2) Perusahaan manufaktur yang mempublikasikan laporan tahunan secara lengkap termasuk pengungkapan tanggungjawab sosial dan tersedia untuk publik di BEI secara berturut-turut selama periode penelitian. Berdasarkan kriteria tersebut, diperoleh sampel sebanyak 32 perusahaan sehingga unit penelitian menjadi $32 \times 3=96$.

\section{Variabel Penelitian dan Definisi Operasional}

1. Pengungkapan Tanggungjawab Sosial (Y)

Pengungkapan CSR adalah data yang diungkapkan perusahaan berkaitan dengan aktivitas sosial yang dilakukan perusahaan (Hackston dan Milne, 1996). Sedangkan definisi operasional praktek pengungkapan sosial yang diterapkan dalam penelitian ini adalah banyaknya item-item pengungkapan sosial yang diungkapkan dalam laporan keuangan tahunan yang dikeluarkan oleh perusahaan. Variabel pengungkapan sosial perusahaan diukur dengan metode content analysis, yaitu suatu metode pengkodifikasian teks dari ciri-ciri yang sama untuk ditulis dalam berbagai kelompok (kategori) tergantung pada kriteria yang ditentukan. (Guthrie, et. Al, 2003). Checklist dilakukan dilakukan dengan melihat pengungkapan sosial perusahaandalan tujuh kategori yang disebut oleh Heckston dan Milne (1996), yaitu lingkungan, energi, kesehatan dan keselamatan tenaga kerja, lain-lain tenaga kerja, produk, keterlibatan masyarakat dan umum. Ketujuh kategori tersebut terbagi dalam 90 item pengungkapan. Menurut Sembiring (2005), berdasarkan peraturan Bapepam No. VIII.G.2 dari 90 item tersebut kemudian disesuaikan dengan kondisi di Indonesia sehingga menjadi 72 item pengungkapan. Setiap item yang ada dalam laporan tahunan perusahaan maka diberi skor 1 dan jika tidak ada diberi skor 0 . Item pengungkapan dalam penelitian ini kemudian dinyatakan dalam bentuk indeks pengungkapan CSR, diukur dengan menggunakan rasio yang diperoleh melalui rumus :

$$
C S R=\frac{\text { Jumlah item CSR yang diungkapkan perusahaan }}{78 \text { item informasi CSR }}
$$

2. Ukuran Perusahaan $\left(\mathrm{X}_{1}\right)$

Ukuran perusahaan adalah suatu skala dimana dapat diklasifikasikan besar atau kecilnya perusahaan. Dalam penelitian ini indikator yang digunakan adalah untuk mengukur tingkat ukuran perusahaan adalah total aktiva. Ukuran perusahaan diproksikan dengan log natural total aset, tujuannya agar mengurangi perbedaan yang signifikan antara ukuran perusahaan besar dan kecil sehingga data total aset terdistribusi normal. Rumusnya adalah:

$\begin{aligned} \text { Size }= & \text { Log Natural Total Aktiva } \\ & \text { Perusahaan }\end{aligned}$

3. Profitabilitas $\left(\mathrm{X}_{2}\right)$ 
Profitabilitas diartikan sebagai kemampuan perusahaan untuk menghasilkann laba atau profit dalam upaya meningkatkan nilai pemegang saham. Variabel profitabilitas dalam penelitian ini menggunakan Return On Asset (ROA). ROA merupakan ukuran efektifitas perusahaan di dalam

4. Leverage $\left(\mathrm{X}_{3}\right)$

Leverage diartikan sebagai tingkat ketergantungan perusahaan terhadap hutang dalam membiayai kegiatan operasinya, dengan demikian leverage juga mencerminkan tingkat risiko keuangan perusahaan. (Sembiring, 2005). Dalam penelitian ini indikator yang digunakan untuk mengukur leverage adalah Debt to Equity Ratio (DER). Pengukurannya dengan menggunakan rumus :

$$
D E R=\frac{\text { Total Kewajiban }}{\text { Ekuitas Pemegang Saham }}
$$

5. Ukuran Dewan Komisaris $\left(\mathrm{X}_{4}\right)$

Ukuran dewan komisaris (UDK) dalam penelitian ini banyaknya jumlah anggota dewan komisaris dalam suatu menghasilkan keuntungan dengan memanfaatkan aktiva yang dimilikinya

- Adapun pengukurannya dengan menggunakan rumus :

$$
R O A=\frac{\text { Laba bersih setelah pajak }}{\text { Total Aktiva }}
$$

perusahaan. Ukuran dewan komisaris dalam penelitian ini dilihat dari banyaknya jumlah anggota dewan komisaris perusahaan. Pengukurannya menggunakan rumus :

$U D K$

$=\sum$ Dewan Komisaris Perusahaan

\section{HASIL ANALISIS DAN PEMBAHASAN}

\section{Analisis Deskriptif Statistik}

Penelitian ini menggunakan 7 tema pengungkapan sosial yang secara keseluruhan terdiri dari 78 item dalam CSR dan 4 variabel digunakan sebagai predictor. Deskripsi hasil penelitian dapat dilihat sebagai berikut :

Tabel 1. Deskripsi Variabel Penelitian

\begin{tabular}{|c|c|c|c|c|c|}
\hline Variabel & $\mathbf{N}$ & Minimum & Maximum & Mean & Std. Deviation \\
\hline CSR & 96 & .04 & .31 & .1211 & .06067 \\
SIZE & 96 & 117677293414 & 153521000000000 & 8493109935546,62 & 23343788788207,082 \\
ROA & 96 & -.76 & .42 & .0630 & .14837 \\
DER & 96 & -2.04 & 8.61 & 1.5732 & 1.78002 \\
UDK & 96 & 2.00 & 11.00 & 4.3333 & 2.090092 \\
\hline
\end{tabular}

Aset yang semakin besar menunjukkan lebih banyaknya sumbersumber aset yang dimiliki perusahaan, sehingga dimungkinkan akan menambah pengungkapan yang dapat diberikan perusahaan.karena data total aset dari sampel perusahaan memiliki variasi yang sangat besar (standar deviasi yang besar), maka data ukuran perusahaan dan sesuai dengan penelitian terdahulu, selajutnya variabel ukuran perusahaan akan disajikan dalam bentuk transformasi logaritma natural dari total aset.

\section{Uji Kualitas Data}

Agar model regresi yang digunakan dalam penelitian ini secara teoritik menghasilkan nilai parametrik yang sesuai dengan asumsi Ordinary Least Squares (OLS), data harus memenuhi tiga asumsi klasik, yaitu :

a. Uji Normalitas 
Bertujuan untuk menguji apakah dalam sebuah model regresi, variabel dependen dan independen, atau keduanya mempunyai distribusi normal atau tidak. Untuk menguji nomal data dalam penelitian ini menggunakan nilai uji Kolmogorov - Smirnov dengan hasil yang menunjukkan signifikansi di atas 0,05 . Hal ini dapat dilihat dari Asymp. Sig. (2tailed) Sig 0,486 > $\alpha$ 0,05 sehingga model regresi sudah memiliki distribusi normal.

b. Uji Heteroskedastisitas

Berdasarkan hasil uji heteroskedastisitas dengan menggunakan uji Glejser diperoleh dari nilai Sig > 0,05 sehingga dapat dikatakan bahwa tidak terdapat heteroskedastisitas dan hasil uji dapat dilanjutkan.

c. Uji Multikolinearitas

Hasil pengujian tolerance menunjukkan tidak ada variabel bebas memiliki nilai tolerance kurang dari 0,10 (10\%). Hasil perhitungan VIF juga menunjukkan bahwa tidak ada variabel yang memiliki nilai lebih dari 10. Dapat disimpulkan tidal ada multikolinearitas.

\section{Pengujian Autokorelasi}

Pengujian autokorelasi bertujuan untuk menguji apakah dalam model regresi linear ada korelasi antara kesalahan penganggu pada periode tertentu dengan kesalahan pada periode sebelumnya. Hasil pengujian Durbin-watson dalam penelitian ini memiliki nilai 1,580 berada antara -2 sampai +2 maka tidak terjadi autokorelasi dalam mkdel regresi yang terbentuk.

\section{Analisis Regresi Linear Berganda}

Analisis ini digunakan untuk mendapat koefisien regresi yang akan menentukan apakah hipotesis yang dibuat akan diterima atau tidak. Hasil analisis regresi dapat dilihat pada tabel berikut :

Tabel 2. Hasil Analisis Regresi Linier Berganda

\begin{tabular}{|r|r|r|r|r|r|}
\hline \multirow{2}{*}{ Model } & \multicolumn{2}{|c|}{$\begin{array}{c}\text { Standardized } \\
\text { Unstandardized Coefficients }\end{array}$} & \multicolumn{2}{|c|}{ Coefficients } & \multirow{2}{*}{ Sig. } \\
\cline { 2 - 3 } & \multicolumn{1}{|c|}{ B } & Std. Error & \multicolumn{1}{|c|}{ Beta } & & .000 \\
1 (Constant) & -.339 & .090 & & -3.786 & .000 \\
Ln_SIZE & .016 & .003 & .503 & 4.650 & .587 \\
ROA & -.019 & .035 & -.047 & -.545 & .019 \\
DER & -.007 & .003 & -.197 & -2.392 & .153 \\
UDK & .005 & .003 & .156 & 1.441 & \\
\hline
\end{tabular}

a. Dependent Variabel: CSR

Persamaan regresi yang dihasilkan adalah sebagai berikut :

$$
\text { CSR }=-0.339+0,016 \text { Size }-0,019 \text { ROA }-0,007 \text { DER + 0,005 UDK + e }
$$

Hasil persamaan menunjukkan bahwa variabel ukuran perusahaan dan dewan komisaris perusahaan memiliki koefisien positif. Hal ini berarti bahwa peningkatan ukuran perusahaan yang dilihat dari total aset dan jumlah anggota dewan komisaris perusahaan akan meningkatkan tanggungjawab sosial perusahaan.

\section{Uji Simultan (Uji F)}

Pengujian ini dugunakan untuk melihat apakah secara keseluruhan variabel bebas mempunyai pengaruh yang bermakna terhadap variabel terikat. Dari hasil 
pengujian dengan nilai $\mathrm{F}$ diperoleh hasil sebagai berikut:

Tabel 3. Hasil Uji F (Uji Anova)

\begin{tabular}{|ll|r|r|r|r|r|}
\hline \multicolumn{1}{|c|}{ Model } & Sum of Squares & \multicolumn{1}{c|}{ df } & Mean Square & \multicolumn{1}{c|}{ F } & Sig. \\
\hline 1 & Regression & 133.608 & 4 & .034 & 14.610 & $.000^{\mathrm{a}}$ \\
& Residual & 176.238 & 91 & .002 & & \\
Total & 309.847 & 95 & & & \\
\hline
\end{tabular}

a. Predictors: (Constant), UDK, DER, ROA, Ln_SIZE

b. Dependent Variable: CSR

Dari tabel diatas didapat nilai $\mathrm{F}$ Hitung sebesar 14,610 dengan tingkat signifikan sebesar 0,000 dan $F$ tabel sebesar 2,472. Karena nilai $\mathrm{F}$ hitung lebih besar dari $\mathrm{F}$ tabel maka dapat disimpulkan bahwa variabel independen yaitu ukuran perusahaan, profitablitias (ROA), leverage (DER) dan ukuran dewan komisaris (UDK) secara bersama-sama berpengaruh terhadap pengungkapan tanggungjawab sosial perusahaan.

\section{Koefisien Determinasi}

Koefisien Determinasi (R2)

digunakan untuk mengetahui persentase pengaruh variabel independen terhadap variabel dependen. Hasil koefisien determinasi dapat dilihat pada tabel berikut

Tabel 3. Koefisien Determinasi

\begin{tabular}{|l|r|r|r|r|}
\hline \multicolumn{1}{|c|}{ Model } & R & \multicolumn{1}{c|}{ R Square } & \multicolumn{1}{c|}{$\begin{array}{c}\text { Adjusted R } \\
\text { Square }\end{array}$} & $\begin{array}{c}\text { Std. Error of } \\
\text { the Estimate }\end{array}$ \\
\hline 1 & $.625^{\mathrm{a}}$ & .391 & .364 & 0.04831 \\
\hline
\end{tabular}

a. Predictors: (Constant), UDK, DER, ROA, Ln_SIZE

b. Dependent Variable: CSR

Besarnya nilai Adjusted $R$ Square dalam model regresi sebesar 0,364 $(36,4 \%)$ menunjukkan bahwa persentase sumbangan besarnya pengaruh variabel independen yaitu ukuran perusahaan, profitablitias (ROA), leverage (DER) dan ukuran dewan komisaris (UDK) terhadap vaiabel dependen yaitu tanggungjawab sosial perusahaan yang diterangkan oleh model penelitian ini adalah sebesar $36,4 \%$. Sedangkan sisanya sebesar $63,6 \%$ dipengaruhi atau dijelaskan olah variabel lain yang tidak dimasukkan dalam model penelitian ini.

\section{Uji Hipotesis}

\section{H1 : Terdapat Pengaruh Ukuran Perusahaan terhadap Pengungkapan CSR}

Hasil penelitian menunjukkan nilai t hitung sebesar 4,650 > t tabel 1,986 dengan tingkat signifikan sebesar 0,000 berada lebih rendah dari $\alpha=0,05$ sehingga hipotesis 1 diterima. Artinya ukuran perusahaan (size) berpengaruh signifikan terhadap pengungkapan tanggungjawab sosial perusahaan.

Ukuran perusahaan merupakan salah satu ukuran penting yang banyak digunakan untuk menjelaskan variasi pengungkapan dalam laporan tahunan perusahaan. Dari hasil pengujian diatas terbukti ukuran perusahaan berpengaruh 
signifikan terhadap pengungkapan CSR, hal ini berarti bahwa perusahaan besar yang dinilai dengan tingkat aktiva yang besar akan mengungkapkan lebih banyak tanggungjawab sosial yang dilakukan oleh perusahaan.

Hasil penelitian ini mendukung penelitian yang dilakukan oleh Belkaoui dan Karpik (1989), Hackston dan Milne (1996), Sembiring (2005), Prima Apriweni (2009), Bramantya Adhi Cahya (2010) dan Aggraeni (2006) yang berhasil membuktikan pengaruh ukuran perusahaan terhadap pengungkapan tanggungjawab sosial perusahaan.

\section{H2 : Terdapat Pengaruh Profitabilitas Perusahaan terhadap Pengungkapan CSR}

Rasio profitabilitas adalah rasio yang digunakan untuk mengukur seberapa efektif perusahaan beroperasi sehingga menghasilkan keuntungan bagi perusahaan. Hasil penelitian menunjukkan nilai $\mathrm{t}$ hitung sebesar $-0,545>\mathrm{t}$ tabel 1,986 dengan tingkat signifikan sebesar 0,587 berada lebih tinggi dari $\alpha=0,05$ sehingga hipotesis 2 ditolak. Dapat disimpulkan bahwa profitabilitas tidak berpengaruh terhadap pengungkapan tanggungjawab sosial perusahaan.

Hasil penelitian ini senada dengan hasil penelitian yang dilakukan oleh Hackston dan Milne (1996), Sembiring (2005), Prima Apriweni (2009), Bramantya Adhi Cahya (2010) dan Aggraeni (2006), Rosmasita (2007) dalam penelitiannya diperoleh hasil bahwa ROA tidak berpengaruh terhadap pengungkapan tanggungjawab sosial perusahan (CSR). Profitabilitas adalah faktor yang menberikan kebebasan dan fleksibilitas kepada manajemen untuk melakukan dan mengungkap kepada pemegang saham program tanggungjawab sosial secara luas. Dengan demikian, semakin tinggi profitabilitas perusahaan maka akan semakin besar pula pengungkapan informasi keuangan.
Namun hubungan antara profitabilitas dan tanggungjawab sosial memungkinkan pula memiliki hubungan negatif. Ketika perusahaan memiliki laba yang tingga, perusahaan tidak perlu melakukan hal-hal yang menganggun informasi tentang suksesnya keuangan perusahaan. sedangkan pada saat tingkat profitabilitas rendah, mereka berharap para pengguna laporan keuangan akan membaca "good news" kinerja perusahaan. Misalnya dalam lingkup sosial, ketika investor membaca laporan pengungkapan tanggunjawab sosial perusahaan diharapkan mereka tetap berinvestasi perusahaan tersebut.

\section{H3 : Terdapat Pengaruh Leverage Perusahaan terhadap Pengungkapan CSR}

Rasio leverage merupakan proporsi total hutang terhadap rata-rata ekuitas pemegang saham. Rasio tersebut digunakan untuk memberikan gambaran mengenai struktur modal yang dimiliki perusahaan, sehingga dapat dilihat tingkat resiko tidak tertagihnya suatu utang. Hasil penelitian menunjukkan nilai $\mathrm{t}$ hitung sebesar $-2,392<\mathrm{t}$ tabel -1,986 dengan tingkat signifikan sebesar 0,019 berada lebih rendah dari $\alpha=0,05$ sehingga hipotesis 3 diterima. Artinya leverage perusahaan berpengaruh signifikan dan negatif terhadap pengungkapan tanggungjawab sosial perusahaan.

Hasil penelitian ini senada dengan hasil penelitian yang dilakukan oleh Belkaoui dan Karpik (1989), Prima Apriweni (2009), Bramantya Adhi Cahya (2010) tetapi berbeda dengan hasil penelitian Sembiring (2005) dan Aggraeni (2006), Rosmasita (2007) yang tidak menemukan hubungan antara tingkat leverage perusahan terhadap pengungkapan tanggungjawab sosial yang dilakukan perusahaan.

Akan tetapi penelitian ini mendukung teori agensi, yang menyatakan bahwa tingkat leverage menpunyai pengaruh negatif terhadap pengungkapan 
tanggungkawab sosial. Manajemen perusahaan dengan tingkat leverage yang tinggi cenderung mengurangi pengungkapan tanggungjawab sosial yang dibuatnya agar tidak menjadi sorotan dari para debtholders (Sembiring, 2005).

\section{H4 : Terdapat Pengaruh Ukuran Dewan Komisaris Perusahaan terhadap Pengungkapan CSR}

Ukuran dewan komisaris adalah jumlah anggota dewan komisaris yang dimiliki perusahaan. semakin besar dewan komisaris, semakin banyak pihak yang dapat melakukan pengawasan terhadap manajemen, sehingga banyak pula butirbutir informasi yang mendetail yang dituntut untuk dibuka dalam laporan tahunan. Hasil penelitian menunjukkan nilai t hitung sebesar 1,441 < t tabel 1,986 dengan tingkat signifikan sebesar 0,153 berada lebih tinggi dari $\alpha=0,05$ sehingga hipotesis 4 ditolak. Artinya ukuran dewan komisaris tidak berpengaruh terhadap pengungkapan tanggungjawab sosial perusahaan. Hal ini menjelaskan bahwa besar kecilnya ukuran dewan komisaris tidak mempengaruhi pengungkapan CSR.

Hasil penelitian ini tidak sejalan dengan Sembiring (2005) yang menunjukkan bahwa dewan komisaris berpengaruh terhadap pengungkapan CSR. Ditolaknya hipotesis ini diduga karena dewan komisaris merupakan wakil shareholders dalam perusahaan yang berfungsi mengawasi pengelolaan perusahaan yang dilakukan oleh manajemen. Sebagai wakil dari shareholders dewan komisaris akan membuat kebijakan menggunakan laba perusahaan untuk ektivitas operasional perusahaan yang lebih menguntungkan daripada melakukan aktivitas sosial.

\section{KESIMPULAN DAN SARAN}

\section{Kesimpulan}

Penelitian menunjukkan bahwa size perusahaan, profitabilitas, leverage dan ukuran dewan komisaris secara simultan berpengaruh signifikan terhadap pengungkapan tanggung jawab sosial perusahaan. Secara parsial, ukuran perusahaan dan leverage berpengaruh signifikan terhadap pengungkapan tanggung jawab sosial perusahaan. Sedangkan profitabilitas dan ukuran dewan komisaris tidak berpengaruh terhadap pengungkapan tanggung jawab sosial perusahaan.

Saran

Untuk penelitian selanjutnya dapat menambah variabel independen yang terkait dengan pengungkapan CSR, seperti tipe industri, kepemilikan manajemen dana lain-lain. Penelitian dapat juga dilakukan dengan memperpanjang periode pengamatan sehingga dapat mempertinggi daya uji empiris.

\section{DAFTAR PUSTAKA}

Al-Qur'annul karim, surat Al-Isra', ayat 36 Anggraini, Fr. Reni Retna, 2001, Pengungkapan Informasi Sosial dan Faktor-faktor yang Mempengaruhi Pengungkapan Informasi Sosial dalam Laporan Keuangan Tahunan (Studi Empiris pada Perusahaanperusahaan yang Terdaftar di Bursa Efek Jakarta). Simposium Nasional Akuntansi 9.

Apriwenni Prima, 2008, Faktor-faktor yang Mempengaruhi Pengungkapan Corporate Social Responsibility pada Laporan Tahunan Perusahaan untuk Industri Manufaktur tahun 2008, Jurnal Ekonomi dan Bisnis Volume 6 Nomor 1, April 2009

Belkaoui, A. And P. G. Karpik, 1989, Determinants of The Corporate Decison to Disclose Social Information, Accounting, Auditing and Accountability Journal, Vol. 2, No. 1:36-51 
Cahya, Bramantya Adhi, 2010, Pengaruh Kinerja Keuangan terhadap Tanggungjawab Sosial (Studi pada Bank di Indonesia periode 20072008), Skripsi di publikasikan, Universitas Diponegoro, Semarang

Ghozali, Imam, 2005, Aplikasi Analisis Multivariat dengan Program SPSS, Edisi Ketiga, Semarang: Badan Penerbit Universitas Diponegoro

Guthrie, et. al. 2004, Using Content Analysis as a Research Method to Inquire Into Intellectual Capital Reporting, Journal of Intellectual Capital. Vol. 5. No. 2. Pp 282-293

Hackston, D. And M.J. Milne, 1996, Some Determinant of Social and Enviromental Disclosures in New Zealand Companies, Accounting, Auditing and Accountability Journal, Vol. 9 No. 1 :77-108

Jose, A. Dan Shang-Mei L. 2006, Enviromental Reporting of Global Corporations : A Content Analysis Based on Website Disclosure, Journal of Business Ethics. Vol 72. Pp. 307-321

Mulyadi, 2002, Auditing, Jilid 1, Edisi Enam, Jakarta : Salemba Empat

Owen, David. 2005, CSR after Enron: A Role for Academic Accounting Proffesion?, Working Paper, Social Science Research Network

Rosmasita, 2007, Faktor-faktor yang mempengaruhi Pengungkapan Sosial (Social Disclosure) dalam Laporan Keuangan Tahunan Perusahaan Manufaktur pada Bursa Efek Jakarta, Skripsi dipublikasikan, Universitas Islam Indonesia

Sembiring, Edi Rismanda, 2005, Karakteristik Perusahaan dan
Pengungkapan Tanggungjawab Sosial pada Perusahaan yang tercatat di Bursa Efek Jakarta, makalah disampaikan pada Simposium Nasional Akuntansi 7, Solo 15-16 Desember 2005 